\title{
エチルベンゼン酸化における $\mathrm{MoO}_{3}-\mathrm{SnO}_{2}$ 触媒 の構造と活性 ${ }^{*}$
}

\author{
荒木道 郎**, 西 村 功**, 早川孝**, 石川敏夫**
}

\begin{abstract}
Structure and Activity of $\mathrm{MoO}_{3}-\mathrm{SnO}_{2}$ Catalyst for Oxidation of Ethylbenzene*
by Michio Araki**, Tsutomu Nishimura**, Takashi Hayakawa** and Toshio Ishikawa**
\end{abstract}

\begin{abstract}
Summary : The relationship between the activity of molybdenum-rich $\mathrm{MoO}_{2}-\mathrm{SnO}_{2}$ catalyst for the oxidation of ethylbenzene and its structure was studied. It was found that the binary catalyst containing small amount of $\mathrm{SnO}_{2}\left(\mathrm{Sn} / \mathrm{Mo}=0.025 \sim 0.2\right.$, atomic ratio) showed higher activity than $\mathrm{MoO}_{3}$ or $\mathrm{SnO}_{2}$ catalyst. No solid solution or chemical compound other than molybdenum trioxide or stannic oxide was observed in the binary catalyst by means of X-ray diffraction. DTA or IR spectroscopy. On the other hand, according to the results of $\mathrm{X}$-ray diffraction, it was considered that the smaller crystallites of stannic oxide, which are almost the same size with the different composition of the catalysts, are dispersed on the surface of the larger crystallites of molybdenum trioxide. ESR spectra of the binary catalyst showed that the amount of $\mathrm{Mo}^{5+}$

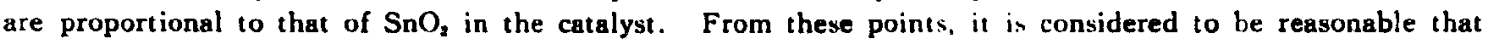
the $\mathrm{Mo}^{\text {s+ }}$ ions exist along the boundaries of two kinds of oxide and $\mathrm{Mo}^{\mathrm{it}}$ ions near the surface worked as the active centre for ethylbenzene oxidation.
\end{abstract}

\section{1 粕 晋}

Mo-Sn 䖵媒を用いろプロピレン臤化に阳する研究は最近い

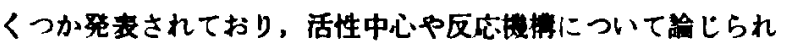
ている。例えば, Lazukin ら”は Mo 量の多いMo-Sn 螌媒で は $\mathrm{SnO}_{2} \cdot 2 \mathrm{MoO}_{2}$ 上 $\mathrm{MoO}$, 上の混合物が, $\mathrm{Mo}$ 量の少市い烛 葉では $\mathrm{MoO}_{2} の \mathrm{SnO}_{2}$ 一の固溚体が，それぞれブロビレン酸 化の活性中心となり，後者がより高活性である上述へている。

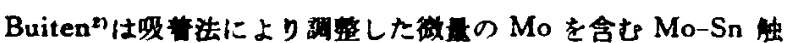
媒を用いて水無気存在下でプロピレン酸化を行い， $\mathrm{SnO}_{2}$ 表面

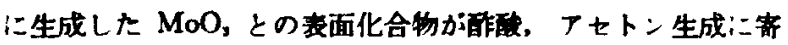
与していると考えた。 Malgolis" は Mo-Sn 蚛媒共面の $\mathrm{Mo}^{8+}$

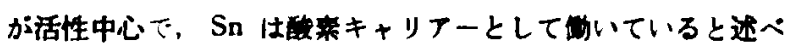
こいる。 Takita !,"は Mo-Sn 蚛其のプレンステッド酸点が プロピレンの能化的水和反度の活性中心であることを見いだし t。

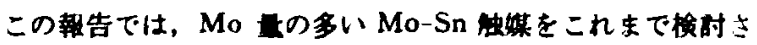
れていないェチルベンゼン化に適用し，さらに出媒椣造を模

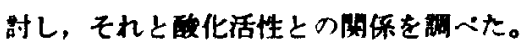

\section{2 実喝}

2.1 反店

不しゅう製反店管 (内径 $10 \mathrm{~mm}$, 最さ200 $\mathrm{mm}$ )をしつ固定 床流通式反庆装㫫を用いてエチルペンゼン空気酸化を行った。 反応条件は, 酸慗/エチルペンゼン =0.9 (モル比), GH SV= $4,000 \mathrm{hr}^{-1}$, 反応温度は 330 から $390^{\circ} \mathrm{C}$ の簀囲とした。

* 昭和 49 年 1 月 14 日受理

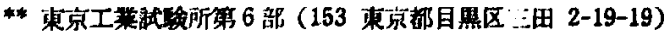
National Chemical Laboratory for Industry, 6th Div. (19-19, 2-chome, Mita, Meguro-ku, Tokyo 153)

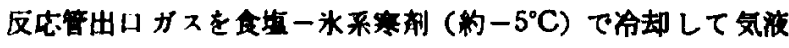
分礼しに後，ガスクロマトグラフを用いてそれそれの組成を分

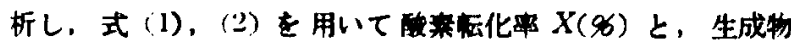

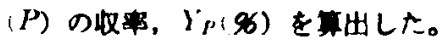

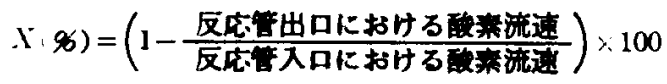

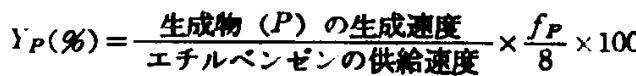

ここで, $f_{P}$ は各生成物一分子中に含まれる炭婪数を表す。

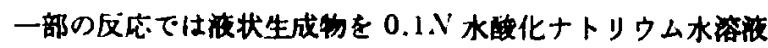
で济定し、エチルベンゼンから当モルい安婜翻が生成すると

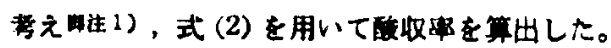

X゙よび Y

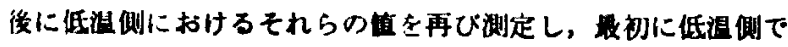
得られた做と一致ナることを属かめた。

\section{2 监およひ反庶原料}

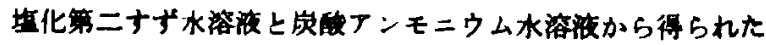

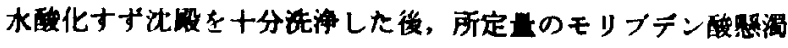

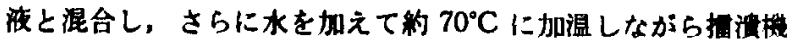
で数時間よく緗った。得られたペースト状物哲を $110^{\circ} \mathrm{C}$ で乾 婐， $450^{\circ} \mathrm{C}$ で 5 時間烧成したものを破碎し，その5ちの 30 か ら40メッシニ分を触媒として用いた。単一組成の酸化モリブ デ触媒と酸化すナ゙䖵禁は，それぞれ，モリブデン酸と前述の

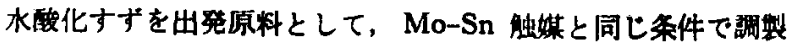

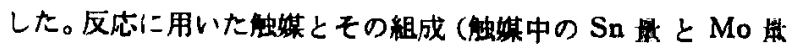
の原子比）を後述する反级結果と共に Table 1 に示した。な

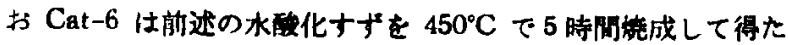
酸化すナとモリブテン椄を原料として前述の方法にならって，

脚让１）称外收スー゙クトルとガスクロマトグラムより生成物中に安息 酸が含まれていることを礁思した。 
Table 1 Oxidation of Ethylbenzene on Mo-Sn Catalyst

\begin{tabular}{|c|c|c|c|c|c|c|c|c|c|}
\hline \multirow{2}{*}{ Catalyst No. } & \multirow{2}{*}{$\begin{array}{c}\text { Composition of } \\
\text { Catalyst } \\
\text { Sn/Mo (atomic ratio) }\end{array}$} & \multirow{2}{*}{$\begin{array}{c}\text { Conversion } \\
\text { of Oxygen } \\
\text { (\%) }\end{array}$} & \multicolumn{6}{|c|}{ Yield of Product (\%) } & \multirow{2}{*}{ Remarks } \\
\hline & & & Styrene & $\begin{array}{c}\text { Benzalde- } \\
\text { hyde }\end{array}$ & Benzene & $\begin{array}{l}\text { Carbon } \\
\text { Dioxide }\end{array}$ & \begin{tabular}{|c|} 
Carbon \\
Monoxide
\end{tabular} & Acid & \\
\hline 1 & 0 & 5 & 2.2 & 0.2 & 0.0 & 0.3 & 0.1 & 0.7 & N \\
\hline 2 & 0.025 & 58 & 4.3 & 1.0 & 0.1 & 2.8 & 1.6 & 5.4 & \\
\hline 3 & 0.05 & 87 & 5.1 & 1.0 & 0.0 & 3.8 & 2.3 & - & \\
\hline 4 & 0.1 & 78 & 4.8 & 1.1 & 0.0 & 4.0 & 2.3 & - & \\
\hline 5 & 0.2 & 89 & 4.6 & 1.3 & 0.4 & 3.6 & 2.5 & 8.6 & \\
\hline - & . & 64 & 3.7 & 0.9 & 0.2 & 2.6 & 1.8 & 6.0 & at $370^{\circ} \mathrm{C}$. \\
\hline - & - & 38 & 2.7 & 0.6 & 0.1 & 1.6 & 1.0 & 3.4 & at $350^{\circ} \mathrm{C}$. \\
\hline - & - & 12 & 1.7 & 0.3 & 0.0 & 1.2 & 0.6 & 0.8 & at $330^{\circ} \mathrm{C}$ \\
\hline $6 \cdot 1$ & 0.2 & 72 & 3.7 & 0.7 & 0.0 & 3.5 & 1.9 & - & (' prepared from stannic \\
\hline 7 & 0.4 & 74 & 3.9 & 1.1 & 0.0 & 3.8 & 2.4 & - & $\begin{array}{l}\text { oxide and molybdic } \\
\text { acid. }\end{array}$ \\
\hline 8 & 0.7 & 19 & 1.6 & 0.2 & 0.0 & 1.0 & 0.6 & 1.6 & \\
\hline $9 b)$ & 0.7 & 38 & 2.3 & 0.4 & 0.1 & 2.1 & 1.1 & - & b) calcined at $550^{\circ} \mathrm{C}$ for \\
\hline 10 & 1 & 14 & 1.4 & 0.1 & 0.0 & 0.6 & 0.3 & - & $5 \mathrm{hr}$. \\
\hline $11^{c 7}$ & $(\infty)$ & 31 & 1.2 & 0.0 & 0.3 & 2.0 & 0.4 & - & c) treated with aqua am- \\
\hline 12 & 10 & 53 & 4.3 & 0.0 & 0.6 & 2.8 & 0.4 & - & monia GHSV=8 \\
\hline 13 & 40 & 21 & 5.9 & 0.0 & 0.3 & 1.4 & 0.3 & 0.3 & \\
\hline 14 & $\infty$ & 21 & 2.6 & 0.0 & 0.3 & 1.9 & 0.2 & 0.0 & \\
\hline
\end{tabular}

These reactions were carried out under the conditions of GHSV $=4,000 \mathrm{hr}^{-1}$, Oxygen/Ethylbenzene $=0.9$ (mole ratio) and reaction temperature $=390^{\circ} \mathrm{C}$.

Cat -9 は Cat -8 tさらに $550^{\circ} \mathrm{C} て ゙ 5$ 時问棁成して、Cat-11

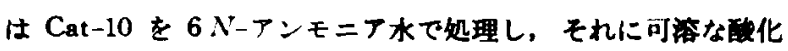

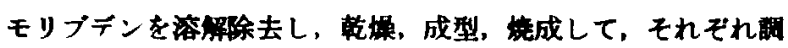

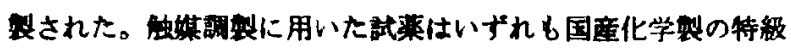
（盐化第二ナナ゙五水醏のみ一般）であった。

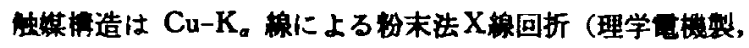

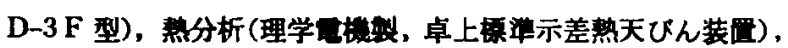
エレクトロンマイクロブロープX線アナライザー（島津 ARL

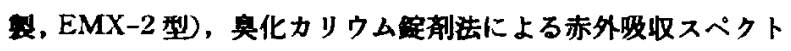
ル（日本分光制，DS-403 G 型)，および ESR（日本而子製） により湖定された。

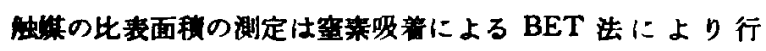
い,その結果を Table 2 に示した。

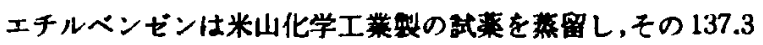
から $137.5^{\circ} \mathrm{C}$ の留分を反心に供した。空気はボンベりのしの をシリカゲル站保管を通してそのまま用いた。

Table 2 Specific Surface Area and Activity of Mo-Sn Catalyat

\begin{tabular}{c|c|c|c}
\hline \multirow{2}{*}{ Catalyst No. } & $\begin{array}{c}\text { Specific Surface } \\
\text { Area }\end{array}$ & $\begin{array}{c}\text { Specific Activity at } 390^{\circ} \mathrm{C} \\
(\mu \text { mol/m-cat } \cdot \text { min })\end{array}$ \\
\cline { 3 - 4 } & $\begin{array}{c}\text { Ethylbenzene } \\
\text { Consumption }\end{array}$ & $\begin{array}{c}\text { Styrene } \\
\text { Production }\end{array}$ \\
\hline 1 & 5.7 & 18.8 & 12.1 \\
2 & 10.8 & 42.0 & 11.2 \\
3 & 17.4 & - & 8.6 \\
4 & 17.1 & - & 6.4 \\
5 & 12.2 & 40.2 & 8.0 \\
6 & 10.0 & - & 11.7 \\
7 & 8.0 & - & 7.4 \\
8 & 2.1 & 34.7 & 10.8 \\
9 & 9.0 & - & 3.7 \\
10 & 2.1 & - & 8.5 \\
11 & 26.1 & - & 2.2 \\
12 & 10.6 & - & 7.4 \\
13 & 52.7 & 3.2 & 2.2 \\
14 & 49.3 & 1.6 & 0.8 \\
\hline
\end{tabular}

\section{3 結 果}

\section{1 反结果}

Mo 量の多いMo-Sn 䖵媒を用いるエチルベンゼン酸化では

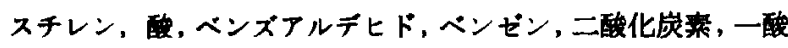
化岸秦等が生成した。ベンズアルデヒド生成は $\mathrm{Mo}-\mathrm{Bi}$ 触媒》

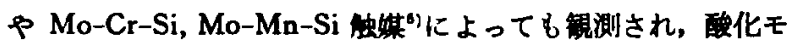

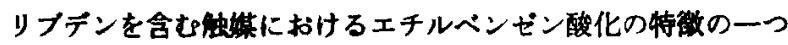
と考えられる。

$\mathrm{Cat}-4(\mathrm{Sn} / \mathrm{Mo}=0.1)$ 上での $350^{\circ} \mathrm{C}$ におりる破秦転化率およ び前述の生成物の収事は，反度 5 時間以内ではほほ一定であっ た。

各租成の Mo-Sn 蝶による $390^{\circ} \mathrm{C}$ における反応結果を Table 1 に示した。破化モリブテン単独の Cat-1 の活性は低

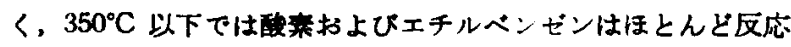
しなかった。Mo-Sn 蝶では，Sn 点の增加とともにスチレ ン収摔は急に增加し， $\mathrm{Sn} / \mathrm{Mo}=0.025 \sim 0.2$ 間（Cat-2, 3, 4,

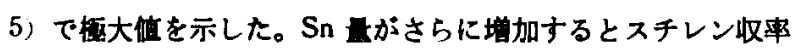
は诚少し, Cat-10 (Sn/Mo=1) で極小值を示したが, Cat-13 $(\mathrm{Sn} / \mathrm{Mo}=40)$ では再び極大值を示した。酸素抎化率や二酸化 苃㙞，一酸化岩秦およびベンゼン収率もスチレン収率と同梯の

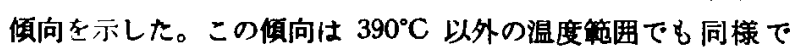
あった。

酸化すず単独の Cat-14 や Sn 量の多いCat-12 および Cat -13では, 酸化モリブデン単独の Cat-1 や Mo 量の多いMo 一n 触媒と比校すると，珻收が低く，ベンズアルデヒドが副

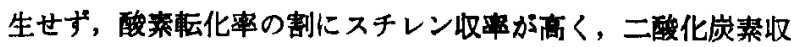
事の割に一酸化岩素収率が極めて低い等の特徽が認められた。

Cat-11 は Cat-10 (Sn/Mo=1) よりアンモニア水で酸化モ リブデを溶解除去した触媒であるが，酸化すず単独の Cat14 と類似の反応結果を示した。

Cat-6 はSn 原料として酸化すずを用いて調制した触媒であ 


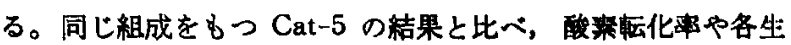

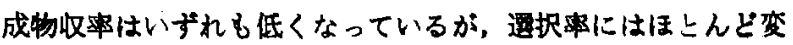
化がなかった。

反态使用後の触媒の BET 比表面積を Table 2 に示した。 酸化モリブデン単独の Cat-1 の比表面核は小さいが，Sn 量が 增加する上 Mo-Sn 触媒の比表面箖は大きくなり，Cat-3（Sn $/ \mathrm{Mo}=0.05)$ で極大值 $\left(17.4 \mathrm{~m}^{2} / \mathrm{g}\right)$ を示した。この便向は活性 の侕向上非常によく似ている。酸化子ず品独のCat-14の比表 面稓は $49.4 \mathrm{~m} / \mathrm{g}$ であった。

これまで酸化ウラニウム舟触媒”におかてェチルベンゼンの 化反态速度式が娭时され，エチルベンゼン消举速度はエチル

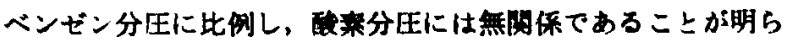

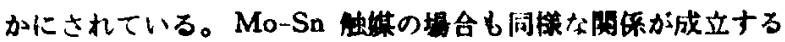
ものとして、エチルぶンゼン消费およびスチレン生成比活性を 算出した。Fig.1 および Table 2 に示したように、エチルの ンゼン消費比活性は Cat-2 から Cat-5 の間で杬大を示し，Sn 量の增加と其に小さくなった。スチレン生成比活性は Cat-1 か ら Cat-12の間では多少のばらつきはあるが俆々に没少し，Cat -13 上 Cat-14においてはさらに娍少した。

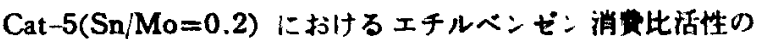

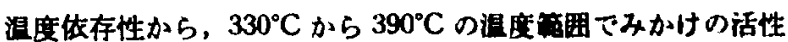
化エネルギーは $20 \mathrm{kcal} / \mathrm{mol}$ であった、

Cat-8 より $100^{\circ} \mathrm{C}$ 漓い $550^{\circ} \mathrm{C}$ で摬成された同粗成の Cat-

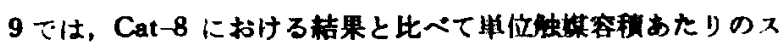

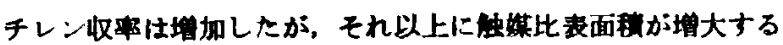
のでスチレン生成比活性は小さくなる。Cat-10 をアンモニア 水で処理してそれに可签な能化モリプデンを悇いたCat-11の 比表面程は Cat-10のそれの的 13 倍の大きさをもつが，酸化 ナナ゙种独の Cat-14のそれの約半分であり，スチレン生成比活 性はその逆の順となった。

\section{2 娂摽造}

粉末法により Mo-Sn 蚛婪の X 線解析を行い次の結果を得 た。MoO,に基づくシャーブな回折ビークと $\mathrm{SnO}_{2}$ に基つくくブロ ードな回折ビークのみが路められた。Cat $-5(\mathrm{Sn} / \mathrm{Mo=0.2)}$

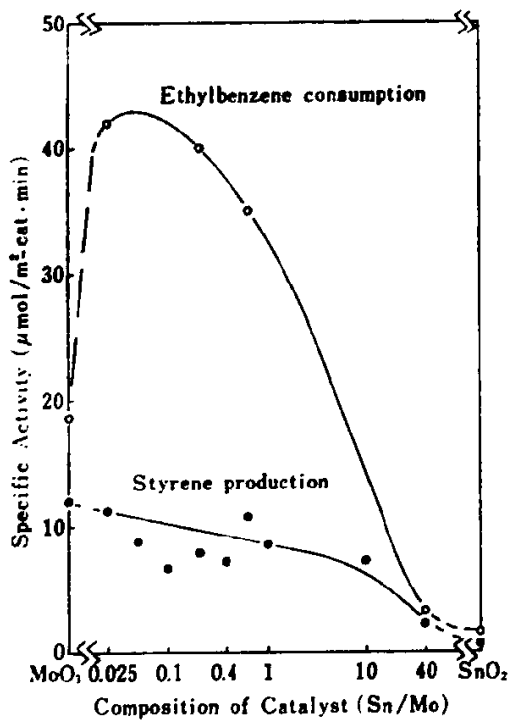

Fig. 1 Catalytic Activity of Mo-Sn Catalyat
ふた付きるつほ中で 5 時間しゃく整して得た 践料のX線回折园にも $\mathrm{MoO}_{3}$ \& $\mathrm{SnO}_{2}$ の回 折ビークのみが顊测さ れ，他の化合物の存在 は、即められなかった。 䖵策組成变化により 回折ピーク強度は变斩 した。ナなかち, Sn 量の增加と共に $\mathrm{MoO}$, の回折ピーク强度は思 速に晹まり，Cat-10，

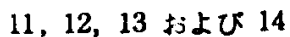
では $\mathrm{SnO}_{2}$ の回折ビー クのみとなった。あら かじ別㑑に娔成して 拉いた $\mathrm{MoO}_{2}$ 上 $\mathrm{SnO}_{2}$

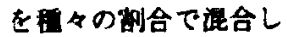

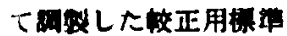
此料のX秋回折では $\mathrm{SnO}, の\left(\begin{array}{lll}1 & 10\end{array}\right)$ 面に 基うく回折ピーク強度 と $\mathrm{MoO}, の(040)$ 面 に䆙つく回折ビーク㟋

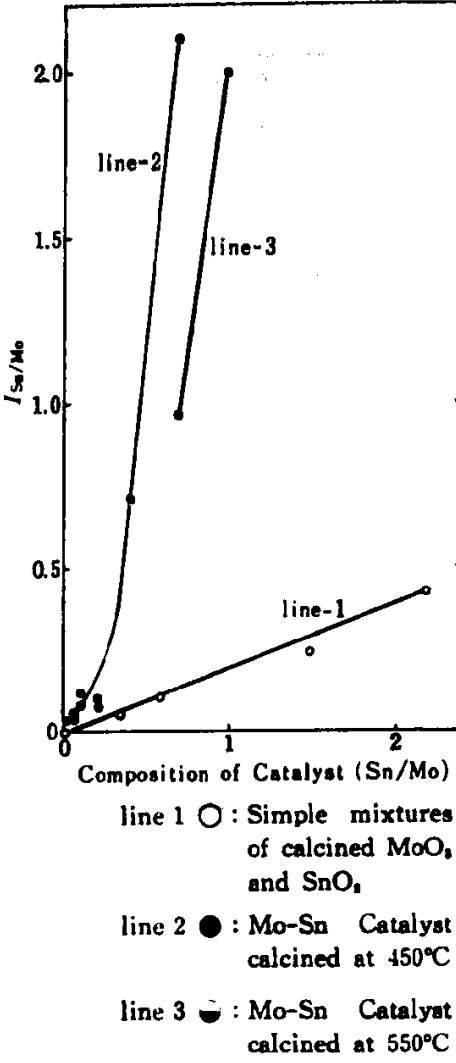

Fig 2 Relationahipe between and Composition of Catalyst

度の比（以下，ISn/Moと表示する）は Fig. 2 に示す上うに武 料中の Sn/Mo (原子比) と比例阙保にあった (line-1)。一方

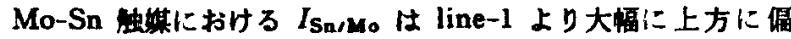

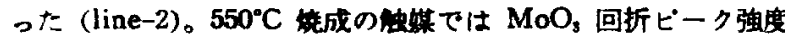
の增大によりその ISa/M。は多少小さくなった（line-3)。

$\mathrm{SnO}_{2}$ の (1 110$)$ 面扰よび $\mathrm{MoO}_{2}$ の (040) 面に基つく回折

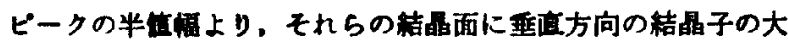
きさ志 Scherrer の式老用いて策出し. Table 3 に示した。蚛 某組成が大きく变化しても $\mathrm{SnO}_{2}$ や $\mathrm{MoO}_{3}$ 結晶子の大きさは ほとんと楚化せだ，それぞれ，的 20 A，約 400 A であった。

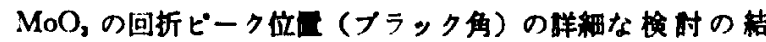
果、そのシフトは微されず， $\mathrm{MoO}_{3}$ は $\mathrm{SnO}_{2}$ と固溶体を形

Table 3 Crystallite Size of $\mathrm{MoO}_{1}$ and $\mathrm{SnO}_{1}$ in Mo-Sn Catalyst

\begin{tabular}{|c|c|c|c|}
\hline \multirow{2}{*}{$\begin{array}{c}\text { Catalyot } \\
\text { No. }\end{array}$} & \multicolumn{2}{|c|}{ Cryatallite Size } & \multirow{2}{*}{ Remarks } \\
\hline & $\mathrm{MoO}_{2}(\AA)$ & $\mathrm{SnO}_{2}(\mathrm{~A})$ & \\
\hline 1 & 470 & & \\
\hline 2 & 480 & 19 & \\
\hline 3 & 450 & 23 & \\
\hline 4 & 430 & 25 & \\
\hline 5 & 420 & $19 \cdot 1 \cdot$ & a) $20 \AA$ : after treatment with \\
\hline 7 & 430 & 19 & aqua ammonia. \\
\hline 8 & 450 & 20 & \\
\hline 9 & 340 & $34^{b)}$ & b) calcined at $550^{\circ} \mathrm{C}$ for $5 \mathrm{hr}$. \\
\hline 10 & - & 190) & c) $20 \AA$ : after treatment with \\
\hline 12 & - & 24 & aqua ammonia. \\
\hline 13 & - & 41 & \\
\hline 14 & & $58^{(3)}$ & $\begin{array}{l}\text { d) } 195 \mathrm{~A} \text { : after heating strong- } \\
\text { ly in crucible for } 30 \mathrm{~min} \text {. }\end{array}$ \\
\hline
\end{tabular}


成していないと考えられる。

蝶は通常 $450^{\circ} \mathrm{C}$ で 5 時间烧成処理を受けた後反忘に用いら

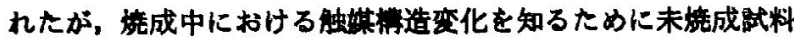
の熱分析を行った。モの結果，付㝜水の離脱による吸等ピーク と重量城少およU゙モりブデン破の分解脱水による樶熱ビークと 重量娍少が覞測された。これら以外には吸発熱ピークおよび重 竞化は䍐められなかった。

エレクトロンマイクロプロープX楾アナライザー（以下 EM Xと略称する）を用いて，Mo-Sn 触媒の同一梘野における反

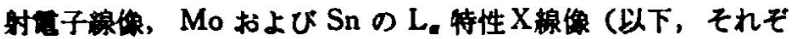

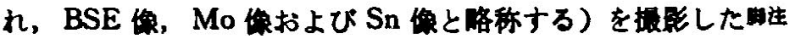

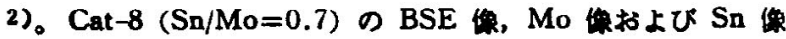

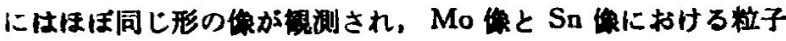

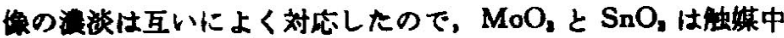
で均一に混在している上考えられる。Cat $-5(\mathrm{Sn} ; \mathrm{Mo}=0.2) の$ BSE 像では Fig. 3 に兮したよ5に，敕百 a大の柆子が混在しているのが思められた。大きい粒テい Mo

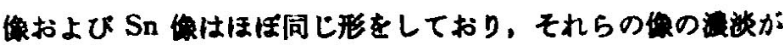
互いによく対応したので， $\mathrm{MoO}_{2}$ と $\mathrm{SnO}_{2}$ は均一に泚在してい 万といえる。一方䄪十少大の粒子群についてはMo侮のみが

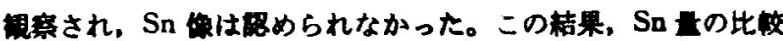
的少ないCat-5 デは $\mathrm{MoO}_{2}$ と $\mathrm{SnO}_{2}$ が均一に存在する部分 上， $\mathrm{MoO}_{3}$ のみの部分がいりまじって蜰某を满成していると考 えられる,

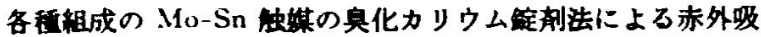
叹スペクトル（测定波長籍用は1100から $350 \mathrm{~cm}^{-1}$ ）をFig. 4

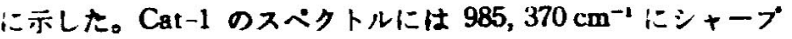
な吸収と $880,580 \mathrm{~cm}^{-1}$ にプロードな吸収が垷楖された。 $\mathrm{Sn}$ 量の堷加により、これらの吸収㤝度は娍少した。それ上ともに $880,370 \mathrm{~cm}^{-1}$ の爰収は低波数例人，580 $\mathrm{cm}^{-1}$ の吸収は高波数

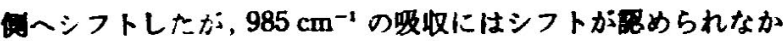
った。Fig.4に示した Cat-14のスベクトルではあまりはっ

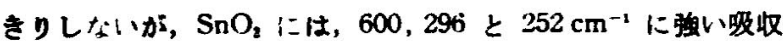

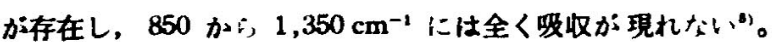
このため，880 $\mathrm{cm}^{-1}$ における暖収シフトは Sn 童変化による $\mathrm{MoO}_{2}$ 上 $\mathrm{SnO}_{2}$ との相互作用の一つのあらわれであり, 370 上 $580 \mathrm{~cm}^{-1}$ における㖟収シフトは婵に $\mathrm{MoO}, 上 \mathrm{SnO}_{2}$ の対応す

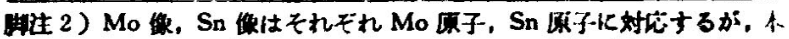

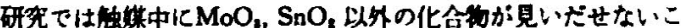

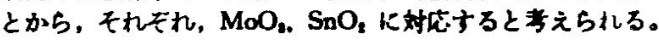

ろ吸収の合成により生じたものと考えられる。

室沮で Mo-Sn 触某の ESR を測定した結果, $g=1.90$ の值 をもつ非效なスベクトルが得られた。句值とその形状から考 えて、このスペクトルは Peacock らりが Bi-Mo 系触媒におい

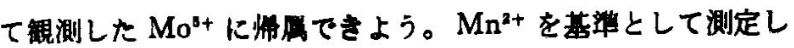
た $\mathrm{Mo}^{5+}$ の相対至は Fig. 5 に示したように Sn/Mo $\leq 0.7$ で

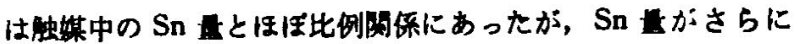
堌加ナると一定值に近ついた。Cat-8 ( $\mathrm{Sn} / \mathrm{Mo}=0.7)$ を水菜一

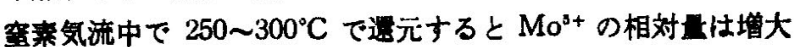
した。

\section{4 考来}

まず虻媒掼造の面から考える。X線回折や熱分析の結果によ う上，本研究に用いられた蝶には $\mathrm{MoO}_{3} \leq \mathrm{SnO}_{2}$ 以外の化

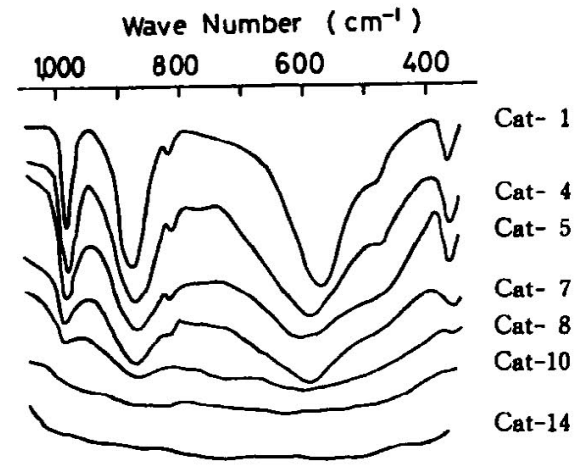

Fig. I Infrared Spectra of Mo-Sn Catalyst

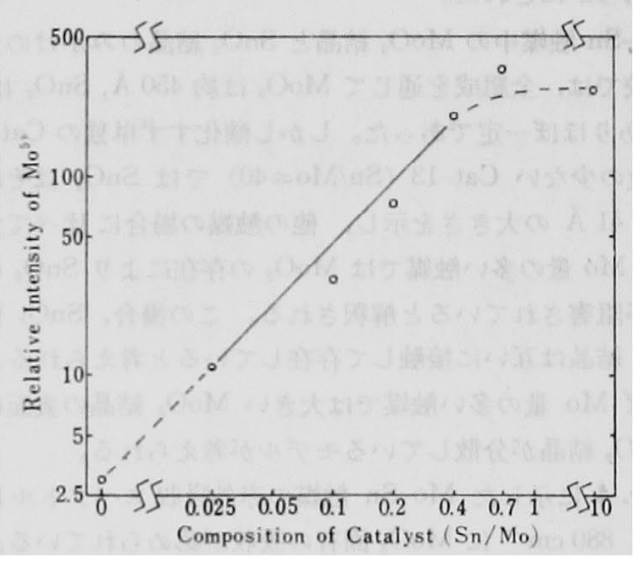

Fig. 5 Relative Intensity of $\mathrm{Mo}^{\text {ot }}$ in Mo-Sn Catalyst

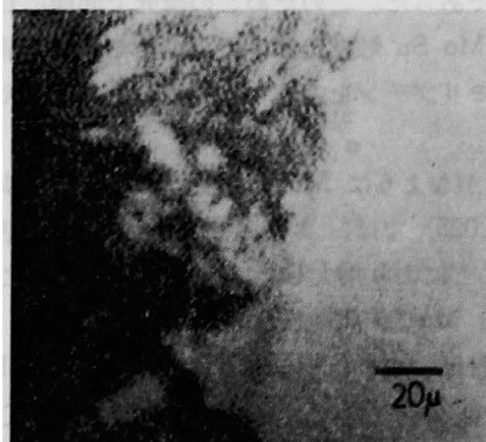

(a) BSE Image

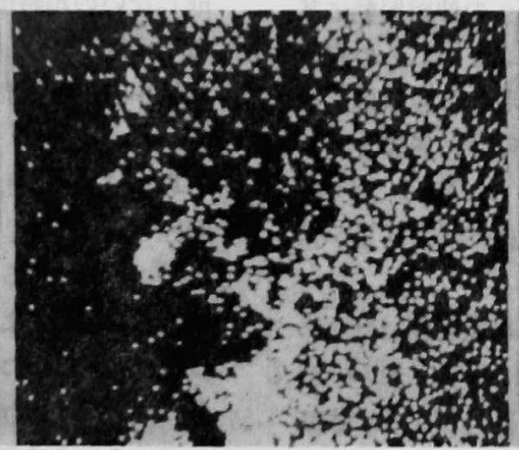

(b) Mo Image

Fig. 3 EMX Images of $\mathrm{Cat}-5(\mathrm{Sn} / \mathrm{Mo}=0.2)$

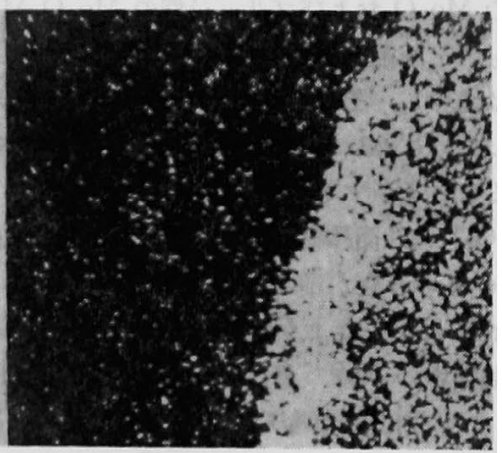

(c) Sn Image

(41) 
合物は見いだせない。またそれらによる固溶体も生成していな いものと思われる。

Lazukin ら"は水酸化第一すずとモリブデン酸とを原料上し $600^{\circ} \mathrm{C}$ て娔成して調製した組成の異なる 9 種の Mo-Sn 蚛蝶の

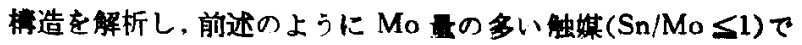
は $\mathrm{MoO}_{3}$ と $\mathrm{SnO}_{3} \cdot 2 \mathrm{MoO}_{3}$ との皘合物よりなり，Mo年の少な い䖵媒（Sn/Mo > 1.9） ては $\mathrm{SnO}_{2} に \mathrm{MoO}_{3}$ が固溶しており， プロピレン酸化に用いた坦合，固溶体の方が $\mathrm{SnO}_{2} \cdot 2 \mathrm{MoO}_{3}$ 上

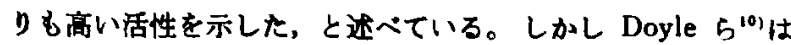
$700^{\circ} \mathrm{C}$ 「 24 時間烧成した各程柤成の十数䀸の $\mathrm{MoO}_{3}-\mathrm{SnO}_{2}$ 混 合物について可視部反射スペクトル测定とX線回折を行い，再 酸化物以外の化合物の存在を否定している。Buiten ${ }^{2}$ は网㱔法

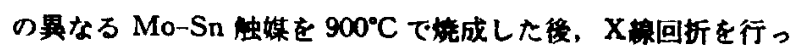
たが新しい:゙クの化合物を見いだせなかった。

このように一般に $\mathrm{MoO}_{3}$ と $\mathrm{SnO}_{2}$ は互いに化合物をつくら

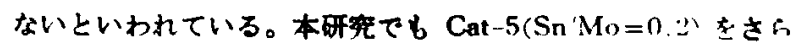

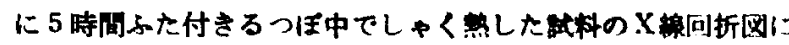

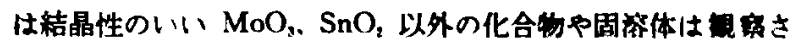

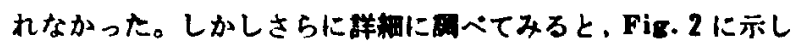
たように䖵媒中における $\mathrm{SnO}_{2}$ 上 $\mathrm{MoO}_{3} の$ X線问折ビー"の

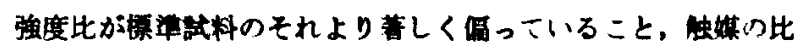

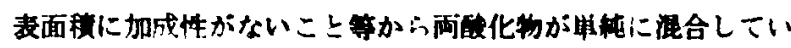
るとは考え的えない。EMX 㒀の結果は巨梘的なしのである が, Fig. 3 に示したように, 比活性の就い Cat-5(Sn/Mo= 0.2 では $\mathrm{MoO}_{3}$ のみが存在している部分と, $\mathrm{SnO}_{2}$ と $\mathrm{MoO}_{3}$ が均一に分布している部分が相察され，均一な湿合物でないこ とが明らかにされた。

Mo-Sn 触娸中の $\mathrm{MoO}_{3}$ 結晶上 $\mathrm{SnO}_{2}$ 結晶のみかけの大きさ の比交では，全組成を通して $\mathrm{MoO}_{3}$ は䄪 $450 \AA, \mathrm{SnO}_{2}$ は約 20 Aでありほぼ一定であった。しかし酸化すず単独のCat-14や Mo 量の少ないCat-13( $\mathrm{Sn} \mathrm{Mo=40)}$ では $\mathrm{SnO}_{2}$ はそれぞれ 58 A，41 A の大きさを示し，他の蝶の煤合に比べて大きい ので, $\mathrm{Mo}$ 量の多い蛅媒では $\mathrm{MoO}_{2}$ の存在により $\mathrm{SnO}_{2}$ の結晶 成艮が阻書されていると解欴される。この域台, $\mathrm{SnO}_{2}$ 結晶上 $\mathrm{MOO}_{2}$ 結晶は互いに接蜰して存在していると考えられる。换官

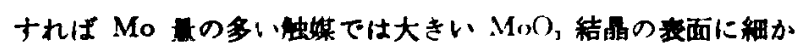
い $\mathrm{SnO}_{2}$ 結晶が分数しているモデルが考えられる。

Pig-4:示した Mo-Sn 体禁の赤外喛収スペクトルには。 985 上 $880 \mathrm{~cm}^{-1} に \mathrm{MoO}$ 固有の昨収が眼められている。これ らは Mitchell ら゙により，それぞれ，八面体栖造の $\mathrm{MoO}_{2} の$ 末端の Mu-O およびブリッジ型の Mo-O-Mo の伸綃报堑に基 うくものと同定されている。Sn 量の㙕加によりこれらの吸取 强度は娍少し,それととしに $880 \mathrm{~cm}^{-1}$ の吸收は低波数侧へシ フトした。このシフトはSn が Mo-O-Mo 結合に影を電をえ ていることを示すものであろ5。Cat-1 から Cat-9 までは [Mo-O.]の八面体棈造は保たれて拈り，X線回折の結果から ๖ $\mathrm{MoO}_{3}$ の存在が示された。

Fig. 5 に示したように, Sn/Mo $\leq 0.7$ の組織筙用では Mo -Sn 触媒中の $\mathrm{Mo}^{\mathrm{s}+}$ 量は $\mathrm{Sn}$ 量と比例開係にあり, $\mathrm{SnO}_{2} か$ $\mathrm{Mo}^{5+}$ の生成に直接開与していると考えられる。Mo-Sn 䖵媒 における $\mathrm{SnO}_{2}$ 結晶の大きさは Cat-13 および Cat-14 をのぞ いてほぼ一定であるので，触媒に含まれる $\mathrm{SnO}_{2}$ の結晶の個数

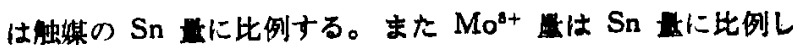
ているので䖵媒中で位位の $\mathrm{SnO}_{2}$ 結前が生成させうる $\mathrm{Mo}^{\mathrm{d}+}$ 異は一定であることになる。このことと前述の $\mathrm{MoO}$ ，上に絴 かい $\mathrm{SnO}_{2}$ が分散している モデルとをあわせると、 $\mathrm{Mo}^{\natural+}$ は $\mathrm{MoO}_{3}$ 結晶と $\mathrm{SnO}$, 結晶との接螌面に生成していると孝えら れる。

Cat $-8(\mathrm{Sn} / \mathrm{Mo}=0.7)$ を $250 \sim 300^{\circ} \mathrm{C}$ で水楼還元すると $\mathrm{Mo}^{\mathrm{lt}}$

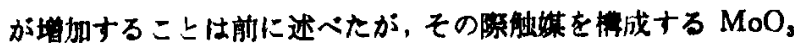
の一部は $\mathrm{MoO}_{2}$ にまで逶元された。しかし $\mathrm{SnO}_{1}$ には变化が

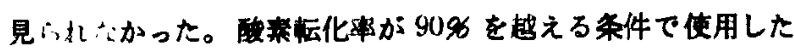

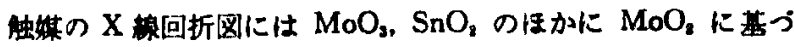
く弱い回折ピーアが出現した。Mo-Sn 蜰媒は MoO, 蜰蜞と比 效すると通元を受けやすい(2)ことが知られているので，蝶中 で $\mathrm{SnO}$ は $\mathrm{MoO}_{3}$ の通元を促進する作用をもち，通元度合の 相进によって $\mathrm{Mo}^{4+}$ ないし $\mathrm{Mo}^{3+}$ を生成するものと思われる。

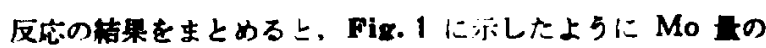
多いMo-Sn 䖵娂のエチルペンゼン酸化比佸珄は化化モリプテ 二䖵（Cat-1）および础化す+䖵媒（Cat-14）のそれのいず れ上りし槀い。特にSn $\mathrm{S10}=0.025 \sim 0.2$ の組成を持つ蚛婪で

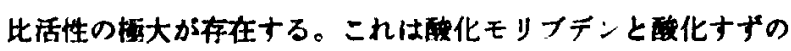
比活性が加成的に現れたしのではなく，而酸化物の組合せによ り新たに卧化活性中心が倜加したものと考えられる。

Lazukin ら"は $\mathrm{SnO}_{2}$ と $\mathrm{MOO}_{2}$ の固体や化含物が活性中心 になると述べているが，本研究での䖵媒造挨封の結果この考 えは否定された

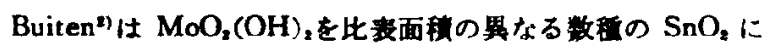

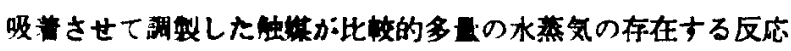

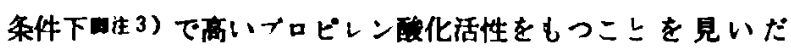
し. $\mathrm{SnO}_{2}$ 上に $\mathrm{MoO}_{2}$ との表面化合物が生成し、これが活性中 心であることを明らかにした。しかしこの表面化合物の存在仕

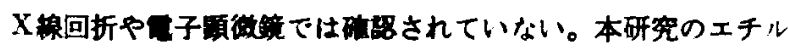

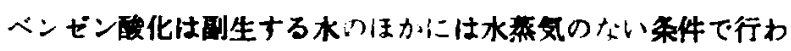

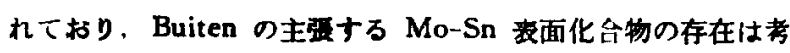
えにくい。

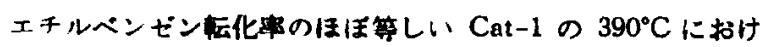
万反応結果と Cat -5 の $330^{\circ} \mathrm{C}$ おび Cat-14の $390^{\circ} \mathrm{C}$ にお ける反忘結果を比䍩した。的二者においてはスチレン，ベンズ

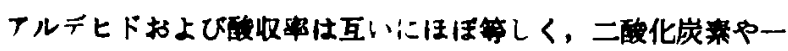

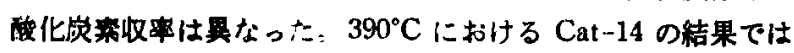

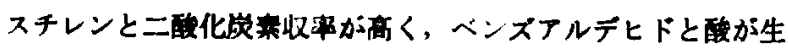
成しないのが特鹳であった。このためこの研究で問頙にしてい る Sn 目の少ないMo-Sn 触婪ではエチルベンゼン部分酸化の 活性中心は，破化モリブデンを主体としているしのと考えられ る。

Fig.1より明らかなように Mo-Sn 触媒の Sn 量が少ない 箱囲 $(\mathrm{Sn} / \mathrm{Mo} \leq 0.025)$ では，エチルベンゼン酸化比活性は $\mathrm{SnO}_{2}$ を添加子ることにより䭪大した。これは Fig. 5 に示す Sn 意の増加に上る $\mathrm{Mo}^{\mathrm{s}+}$ の曙加と対応する。このため $\mathrm{Mo}^{8+}$ はエチルペンゼン酸化活性中心となると教えられる。Malgolis

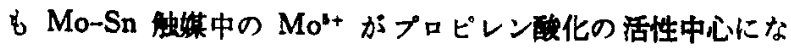
っていることを示した。ESR で測定される $\mathrm{Mo}^{\text {s+ }}$ は触媒表面

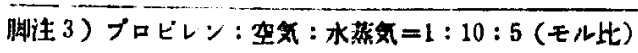


に存在する $\mathrm{Mo}^{\mathrm{s}+}$ と触媒内部に存在する $\mathrm{Mo}^{\mathrm{b}+}$ とにわけられ

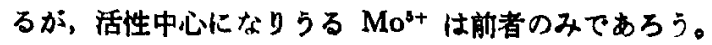
$\mathrm{Mo}^{3+}$ 量は Sn 量が増加すると增大するにしかかわらず. 化比活性は Cat-5 $(\mathrm{Sn} / \mathrm{Mo}=0.2)$ で柜大值となった後、急潄

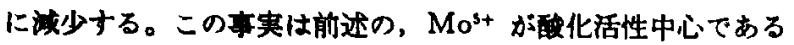
上する僮論上一數しないが、これは次のように孝えるこ上によ り解决される。すなわち、 $\mathrm{Mo}-\mathrm{Sn}$ 触媒中の $\mathrm{SnO}_{2}$ 結晶は $\mathrm{Mo}$ $\mathrm{O}_{3}$ 結晶上に分散しているが，Sn 量が少ない組成笛国では $\mathrm{Sn}$ $\mathrm{O}$ 、佃々の結晶は互いに接触するこ上なく $\mathrm{MoO}_{3}$ 結晶上に存在

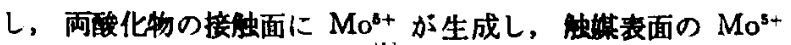
が活性中心こして场く。 $\mathrm{Sn}$ 量が増加するにつれて，MoO, 結 晶上の $\mathrm{SnO}_{2}$ 結晶は一定の大きさを保ったままその個数を增し それに比例して $\mathrm{Mo}^{5+}$ が増え、活性が高くなる。さらに Sn が增えると $\mathrm{MoO}_{3}$ 結晶上で $\mathrm{SnO}_{2}$ 結晶は互いに接钟しはじめ

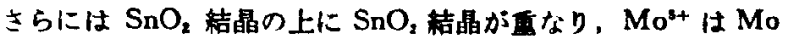
$\mathrm{O}_{3}$ 結晶と $\mathrm{SnO}_{2}$ 結晶の境界再に存在するにもかかからず, 出 媒表面には存在するとはいえない状热になり，话性がさがる。 $\mathrm{Sn}$ 'Mo が非常に大きくなると $\mathrm{MoO}_{3}$ 結晶は $\mathrm{SnO}_{2}$ 結品群に

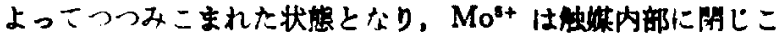
められて活性に関与せナ゙，最終的には $\mathrm{SnO}_{2}$ 䖵基固有の活性に
近つくくものと都えられる。

本研究の实験の一部を担当した伊沢雄一君（当時明治大学学

生)に感时の兴を丧ナ。

$$
\text { 文献 }
$$

1) Lazukin, V. I., Rubanik, M. Ya., Zhigailo, Ya.V., Kurganov, A.A., Buteiko, Zh.F., Chern. Abst., B8, 75620 y(1967); Katal. Katal., Akad. Nauk. Ukr. SSR, Resmeb. Mezhvedom. Sb. NO. 2, 50 (1966).

2) Buiten, J., J. Catalysis, 10, 188 (1968).

3) Malgolis, L.Ya., ibid., 21, 93 (1971).

1) Takita, Y., Ozaki, A., Moro-oka, Y., ibid., 27, 185(1972).

5) Adams, C.R., ibid., 10, 355 (1968).

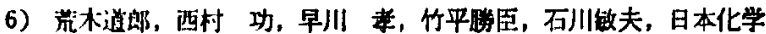
会第 28 香委年会予稿集 (1973).

7）野㥓文男，市川文婎，日化，1973，254.

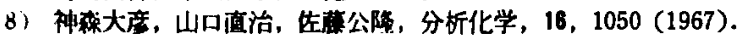

9) Peacock, J. M., Shsrp, M. J., Parker, A. J., Ashmore, P.G., Hockey, J.A., J. Catalysis, 15, 379(1969).

10) Doyle, W. P., Forbes, F., J. Inorg. Nucl. Chem., 21, 1271 (1965).

11) Mitchell, P. C. H., Trifiro, F., J. Chem. Soc., (A) 1870, 3183.

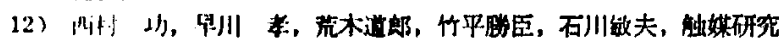

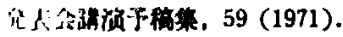

